\title{
THE EFFECT OF DIET CONTAINING HIGH ALPHA-LINOLENIC ACID ON OMEGA-3 FATTY ACIDS AND HEALTH STATUS OF THE HEART IN BROILERS
}

\section{PENGARUH PAKAN YANG MENGANDUNG ASAM ALPHA-LINOLENAT TINGGI TERHADAP ASAM LEMAK OMEGA-3 DAN STATUS KESEHATAN JANTUNG PADA BROILER}

\author{
Lilik Retna Kartikasari*, Robert James Hughes ${ }^{2}$, Mark Geier ${ }^{2}$, and Robert Albert Gibson ${ }^{3}$ \\ ${ }^{1}$ Department of Animal Science, Faculty of Agriculture, Universitas Sebelas Maret, Surakarta, 57126 \\ ${ }^{2}$ South Australian Research and Development Institute (SARDI), South Australia, 5371 \\ ${ }^{3}$ School of Agriculture, Food and Wine, University of Adelaide, South Australia, 5064
}

Submitted: 22 August 2016, Accepted: 5 December 2017

\begin{abstract}
The objective of the study was to examine the effects of diet containing high alpha-linolenic acid (ALA) on omega-3 long chain polyunsaturated fatty acids (n-3 LCPUFA) and the health status of heart in broilers. Diets were based on a commercial starter diet, with a low level of fat. The experimental diets contained two levels of ALA (2.23 and 19.37\%), with the total fat content was approximately $5 \%$. Pure or blended vegetable oils were included at a level of $2.8 \%$ in order to produce diets with the desired levels of linoleic acid (LA) and ALA. The ratio of LA to ALA of the diets was 9.75:1 for low ALA diet and 1.37:1 for high ALA diet. Each diet was provided ad libitum for the duration of the 28-d growth period. A total of 32 one-day-old chicks housed in four pens ( $n=8$ birds/pen). At 28 days of age, six selected birds from each pen were weighed individually and hearts were collected for analysis. A ratio of right ventricle mass (RV) to total ventricle mass (TV) was used to indicate the health status of the heart. Results showed that dietary treatment increased the level of ALA in heart tissue from $0.1 \%$ (low ALA diet) to $0.5 \%$ ( $P<0.01$ ) Increasing levels of dietary ALA raised the level of n-3 LCPUFA and total n-3 in heart tissues by 4-5-fold. There was no significant difference observed in the level of heart LA, arachidonic acid (AA) and total $n-6$. The increased levels of dietary ALA did not cause changes in the ratio of RV to total TV. In conclusion, it appears clear that based on our data, increasing ALA content in the diet of chickens could potentially be beneficial for the health of the birds; however, further work is necessary.
\end{abstract}

(Keywords: Alpha-linolenic acid, Chicken heart, Health status, Omega-3 fatty acids)

\section{INTISARI}

Penelitian dilakukan untuk mengetahui pengaruh pakan yang kaya akan kandungan asam alphalinolenat (alpha-linolenic acid, ALA, asam lemak n-3) terhadap kandungan asam lemak tak jenuh omega-3 rantai panjang ( $n$-3 LCPUFA) dan status kesehatan jantung ayam. Pakan yang diberikan didasarkan pada pakan starter komersial yang mengandung lemak rendah. Pakan perlakuan terdiri dari dua aras ALA (2,23 and 19,37\%), dengan kandungan total lemak sekitar 5\%. Minyak murni dan campuran minyak sayuran ditambahkan dengan aras 2,8\% dengan tujuan menghasilkan pakan dengan tingkat asam linoleat ( $L A$, asam lemak $n-6)$ dan ALA yang diharapkan. Rasio LA terhadap ALA pakan adalah 9,75:1 untuk pakan yang mengandung ALA rendah dan 1,37:1 untuk pakan yang mengandung ALA tinggi. Sejumlah 32 ekor ayam umur satu hari dikandangkan ke dalam empat kandang ( $n=8$ ekor/kandang). Pada umur 28 hari, enam ayam broiler yang terpilih dari masing-masing kandang ditimbang secara individu dan sampel jantung diambil untuk dianalisa. Rasio dari massa ventrikel kanan terhadap massa ventrikel total digunakan untuk menunjukkan status kesehatan dari jantung. Hasil-hasil penelitian menunjukkan bahwa pakan perlakuan meningkatkan kandungan ALA dari 0,1\% (pakan yang mengandung $A L A)$ sampai $0,5 \%(P<0,01)$. Peningkatan aras $A L A$ pakan meningkatkan kandungan asam lemak tak jenuh $n-3$ rantai panjang dan total asam lemak $n-3$ jaringan jantung ayam hingga 4-5 kali lipat. Tidak terdapat perbedaan yang nyata pada kandungan LA, asam arakhidonat (AA) dan total asam lemak n-6. Aras ALA pakan yang ditingkatkan tidak menyebabkan perubahan pada rasio RV terhadap total TV. Berdasarkan data yang diperoleh dapat disimpulkan bahwa peningkatan kandungan ALA pada pakan ayam mempunyai potensi memberikan manfaat kesehatan bagi ayam.

(Kata kunci: Asam alfa-linolenat, Asam lemak omega-3, Jantung ayam, Status kesehatan)

\footnotetext{
* Korespondensi (corresponding author):

Telp. +62 87838658 386, E-mail: lilikretna@staff.uns.ac.id
} 


\section{Introduction}

Ascites and sudden death syndrome (SDS) are the most common heart-related conditions and highly susceptible to heart failure that affects mainly fast-growing broiler chickens. Frequently, birds which die of SDS to be in good condition without any discernible preexisting clinical signs and all birds were well-fleshed and had general pulmonary congestion (Olkowski, 2007). However, birds with history of cardiac rhythm disturbances and showing serious ventricular arrhythmia are at high risk of sudden death. Male birds have higher in the incidence of arrhythmia than females, and the prevalence of SDS is much higher in male meat type poultry (Olkowski and Classen, 1998).

Julian (1998) noted that right ventricular failure following right ventricular hypertrophy (RVH) from pulmonary hypertension causes ascites, which has become a prominent cause of illness and death in broiler chickens. An early sign of right ventricle hypertrophy in the pathogenesis of ascites is higher right ventricle weight to total ventricular weight ratio (Wideman, 2001). The rate of sudden death ranges from 1.3 to $9.6 \%$ depending on the conditions and age of the birds (Gardiner et al., 1988). The sudden death in chickens could have a similarity to sudden cardiac death in humans which has been related to low levels of $n-3$ fats in heart membranes (Albert et al., 1998).

Therefore, the accumulation of heart omega-3 long chain polyunsaturated fatty acids ( $n-3$ LCPUFA) in chickens was measured to examine whether diets high in ALA were potentially beneficial for the health of birds by increasing the level of $n-3$ LCPUFA, eicosapentaenoic acid (EPA), docosapentaenoic acid (DPA) and docosahexaenoic acid (DHA) in cardiac membranes. Support for this comes from previous reports that feeding chickens diets containing $5 \%$ linseed oil reduced right ventricle hypotrophy (Walton et al., 1999) and pulmonary hypertension was reduced in birds fed a diet containing 10\% linseed oil (Bond et al., 1996). The primary objective of the research was to examine the effects of diet containing high ALA on heart $n-3$ LCPUFA levels and the health status of the heart.

\section{Materials and Methods}

\section{Experimental design}

The design of this study was a oneway classification. The variable factor was the ALA level in the diet. The dietary treatments were based on the ratio of LA to ALA of the diets. There was a total of two diets comprised of a low ALA diet and a high ALA. These diets were provided to a total of 32 one-day-old chicks housed in four pens ( $n=8$ birds/pen). Each dietary treatment was assigned to two pens.

\section{Birds}

A total of 32 one-day-old mixed sex broiler chickens (Cobb 500) obtained from the Baiada hatchery (Willaston, SA, Australia) were randomly placed in four pens and distributed between two dietary treatments. The birds were housed for 28 days and reared at PPPI, SARDI, Roseworthy Campus under controlled environmental conditions. Upon arrival from the hatchery, the chickens were immediately weighed in groups of 8 (Libror EB-32KS SHIMADZU) and placed on brown paper in raised rearing pens $(1.2 \times 0.9$ $\mathrm{m}$ each pen). Feed was provided in a plastic hopper and scattered over the paper to encourage the chickens to eat immediately after placement. Fresh water was placed in the splash cup under the drinking nipples to encourage the chickens to drink soon after placement. Both feed and water were provided ad libitum for the duration of the experiment.

Room temperature was maintained at $27^{\circ} \mathrm{C}$ for 4 days and gradually reduced to $20^{\circ} \mathrm{C}$ during the experimental period. All birds were subjected to a $24 \mathrm{~h}$ light program throughout the growth period. At the same time, the pens were also given heat from infrared lamps (175 watts) for 21 days. During the first few days, the chickens were observed at frequent intervals to ensure that they were comfortable with the environmental conditions and that all had access to adequate feed and water. The room temperature was maintained by a logic controller (Tempron 606) which managed air flow, cooling and heating. Fresh wood shavings were put on the pen floor at 3 days old. During the experimental period fresh shavings were added three times. 


\section{Diets}

Diets were based on a commercial starter diet, with a low level of fat (Table 1). The experimental diets were formulated by varying the levels of ALA, which was from 2.23 (diet low in ALA) to $19.37 \%$ (diet high in ALA), with the total fat content was approximately $5 \%$. Pure (macadamia oil) or blended vegetable oils (macadamia and flaxseed oil) were included at a level of $2.8 \%$ to produce diets with the desired levels of LA and ALA.

The dietary treatments had the same nutritional values as the basal diet except for the fatty acid composition. This resulted in the ratio of LA to ALA of the diets 9.75:1 (low in ALA) and 1.37:1 (high in ALA). All diets met or exceeded National Research Council guidelines for broiler chickens. The fatty acids content of the experimental diets is presented in Table 2. Each diet was provided ad libitum for the duration of the 28-d growth period.

\section{Sample collection and fatty acid analysis}

At 28 days of age, six selected birds from each pen (12 birds per dietary treatment group) were weighed individually and hearts were collected for analysis. A ratio of right ventricle mass $(R V)$ to total ventricle mass (TV) was used to indicate the health status of the heart. The heart analysis of birds followed the procedure described by Julian (1987). After dissection, the heart was removed and placed on a paper plate. Auricles, major vessels and fat were stripped from the heart. The RV including the valve was carefully removed from the left ventricle (LV) and septum. The RV was weighed and recorded. The LV and septum were also weighed. These data were used to calculate the percentage values of RV/TV, where TV is

Table 1. Ingredient composition and nutrient content of basal diet

\begin{tabular}{|c|c|}
\hline Ingredients $^{1}$ & $\mathrm{~kg} / 100 \mathrm{~kg}$ \\
\hline Wheat fine & 43.91 \\
\hline Wheat mil vits & 0.80 \\
\hline Barley & 10.00 \\
\hline Triticale fine & 10.00 \\
\hline Peas fine & 10.00 \\
\hline Meat meal & 4.60 \\
\hline Blood meal & 1.40 \\
\hline Soybean meal & 15.00 \\
\hline Millrun & 2.00 \\
\hline Limestone small & 0.79 \\
\hline Salt & 0.18 \\
\hline Sodium bicarbonate & 0.27 \\
\hline Choline chloride $75 \%$ & 0.07 \\
\hline Potassium carbonate & 0.01 \\
\hline L-threonine & 0.09 \\
\hline Alimet & 0.35 \\
\hline Standard broiler starter premix & 0.20 \\
\hline Lysine sulphate & 0.29 \\
\hline Phyzyme XP5000L broiler & 0.01 \\
\hline Feed enzyme premix & 0.03 \\
\hline \multicolumn{2}{|l|}{ Nutrient content (\%) } \\
\hline Metabolizable energy, kcal/kg & 2,787 \\
\hline Crude protein & 22.99 \\
\hline Crude fat & 2.20 \\
\hline Crude fiber & 3.82 \\
\hline Calcium & 0.98 \\
\hline Phosphorus & 0.74 \\
\hline Available phosphorus & 0.5 \\
\hline $\mathrm{Na}$ & 0.2 \\
\hline K & 0.71 \\
\hline $\mathrm{Cl}$ & 0.2 \\
\hline Lysine & 1.3 \\
\hline Methionine & 0.59 \\
\hline Methionine + Cystine & 0.99 \\
\hline
\end{tabular}


Table 2. Fatty acid content of the diets

\begin{tabular}{lcc}
\hline \hline & & Experimental diets \\
\cline { 2 - 3 } & Low ALA Diet & High ALA Diet \\
\hline LA (\% energy, \%en) & 2.34 & 2.90 \\
ALA (\% en) & 0.24 & 2.12 \\
LA:ALA ratio & $9.75: 1$ & $1.37: 1$ \\
Fat (\%) & 5.05 & 5.11 \\
Fatty acid ${ }^{1}$ (\% of total fatty acids) & & \\
Total SFA & 21.37 & 19.41 \\
Totals Trans & 0.39 & 0.42 \\
18:1n-9 & 40.25 & 27.11 \\
18:1n-7 & 2.53 & 1.58 \\
Total MUFA ${ }^{1}$ & 53.85 & 33.80 \\
Total n-9 & 42.40 & 28.34 \\
Total $n-7$ & 11.31 & 5.36 \\
18:2n-6 & 21.63 & 26.52 \\
Total $n-6$ & 21.85 & 26.76 \\
18:3n-3 & 2.23 & 19.37 \\
Total $n-3$ & 2.47 & 19.52 \\
Total PUFA & & 46.28 \\
\hline${ }^{1}$ SFA $=$ saturated fatty acid; MUFA= monounsaturated fatty acid; PUFA= polyunsaturated fatty acid
\end{tabular}

total ventricle and septum weight. A ratio of RV/TV of $<0.25$ (25\%) was classified as a normal broiler (Julian, 1987). Hearts were stored for fatty acid analysis. The fatty acid profile were analysed followed procedures of Kartikasari et al. (2012).

\section{Results and Discussion}

\section{Heart tissue fatty acids}

The fatty acid composition of heart tissues is presented in Table 3. The two diets contained similar levels of dietary LA (around $2 \%$ ) but high ALA group contained 10 times the low level of ALA. Dietary treatment increased the level of ALA in heart tissue from $0.1 \%$ (low ALA diet) to $0.5 \%$. This aspect of the current project was conducted to examine whether increasing the level of dietary ALA was potentially beneficial for the health of fast growing broilers. Our study found that by increasing dietary level of $A L A$, heart membrane n-3 LCPUFA (EPA, DPA and $\mathrm{DHA}$ ) and total $\mathrm{n}-3$ increased 4 to 5 fold. The level of EPA was found in the highest amount $(2.2 \%)$ among $n-3$ LCPUFA and appears as the major n-3 LCPUFA in heart tissues while DHA was less than $1 \%$ of the total fatty acids. This might be because DHA has a limited ability to accumulate in cardiac tissue in chickens. This contrasts with the fatty acid patterns in human hearts where the level of EPA is normally around $0.5 \%$ and DHA is nearly $5 \%$ of the total fats (Metcalf et al., 2007). Feeding fish oil to human subjects has been shown to increase EPA and DHA levels markedly but feeding ALA rich flax oil had no effect (Metcalf et al., 2007).

The results show that the response to saturated fatty acid (SFA) content of heart samples was not different between low ALA diet and the high ALA diet whereas the concentration of monounsaturated fatty acid (MUFA) was reduced $(P<0.05)$. There was no significant difference observed in the level of heart $L A, A A$ and total $n-6$.

\section{Heart analysis}

We observed that there was no difference in the percentage of right ventricle (RV) to total ventricle (TV) of birds with increasing dietary ALA level in the diet using $1.7 \%$ flaxseed oil (Table 3 ). These results are supported by other investigators. Walton et al. (1999) conducted a study in broiler chickens fed diets containing 2.5 or $5 \%$ flaxseed oil or control diets with equivalent amounts of animal/vegetable blend oil for 4 weeks using hypobaric chambers and control pens. They found that the inclusion level of $5 \%$ flaxseed oil in the diet reduced right ventricle hypertrophy in birds exposed to hypobaric conditions compared to the birds fed with control diets. However, there was no change observed in the birds fed with $2.5 \%$ flaxseed oil. Thus our inability to demonstrate a change in ventricular size may have been due to the lower level of flaxseed oil tested (1.7\%).

The ratio of RV to TV both in the low ALA diet (19.12\%) and high ALA diet $(21.39 \%)$ was $<0.25(25 \%)$. It indicates that 
Table 3. Ventricular characteristics and fatty acid composition of heart phospholipids from chickens fed experimental diets varying in LA to ALA ratio for 28 days ${ }^{1}$

\begin{tabular}{|c|c|c|c|c|}
\hline \multirow[t]{2}{*}{ Nutrient content } & \multicolumn{3}{|c|}{ Experimental diets } & \\
\hline & Low ALA diet & High ALA C & & \\
\hline LA (\% en) & 2.34 & 2.90 & & \\
\hline ALA (\% en) & 0.24 & 2.12 & & \\
\hline LA:ALA ratio & $9.75: 1$ & $1.37: 1$ & & \\
\hline Fat content (\%) & 5.05 & 5.11 & & \\
\hline Fatty acids ${ }^{2}$ & \multicolumn{2}{|c|}{ (\% of total fatty acids) ${ }^{1}$} & PSEM & $P$ value \\
\hline 16:0 & 16.83 & 16.97 & 0.601 & NS \\
\hline 18:0 & 20.68 & 21.44 & 0.481 & NS \\
\hline SFA & 41.59 & 42.97 & 0.323 & NS \\
\hline $18: 1 n-9$ & $13.74^{b}$ & $10.31^{\mathrm{a}}$ & 0.260 & * \\
\hline $18: 1 n-7$ & 3.98 & 3.02 & 0.196 & NS \\
\hline MUFA & $19.88^{b}$ & $14.59^{a}$ & 0.446 & * \\
\hline $20: 3 n-9$ & $1.55^{\mathrm{b}}$ & $0.78^{a}$ & 0.063 & * \\
\hline $18: 2 n-6$ & 25.43 & 25.93 & 0.729 & NS \\
\hline $20: 3 n-6$ & 1.50 & 1.33 & 0.109 & NS \\
\hline $20: 4 n-6$ & 7.46 & 8.22 & 0.684 & NS \\
\hline Total n-6 & 35.57 & 36.63 & 0.408 & NS \\
\hline $18: 3 n-3$ & $0.08^{a}$ & $0.48^{\mathrm{b}}$ & 0.017 & $* *$ \\
\hline $20: 3 n-3$ & $0.06^{a}$ & $0.21^{b}$ & 0.010 & ** \\
\hline $20: 5 n-3$ & $0.44^{a}$ & $2.21^{\mathrm{b}}$ & 0.090 & ** \\
\hline $22: 5 n-3$ & $0.25^{a}$ & $1.15^{\mathrm{b}}$ & 0.053 & ** \\
\hline $22: 6 n-3$ & $0.14^{a}$ & $0.64^{\mathrm{b}}$ & 0.012 & ** \\
\hline Total n-3 & $0.99^{a}$ & $4.71^{\mathrm{b}}$ & 0.018 & ** \\
\hline Total PUFA & $36.56^{\mathrm{a}}$ & $41.34^{\mathrm{b}}$ & 0.410 & * \\
\hline \multicolumn{5}{|l|}{ RV/TV ratio (\%) } \\
\hline RV/TV & 19.12 & 21.39 & 1.225 & NS \\
\hline
\end{tabular}

a,b Values in the same row with no common superscript are significantly different

${ }^{1}$ Fatty acid values are means of 12 observations per treatment

${ }^{2} \mathrm{SFA}=$ saturated fatty acid; MUFA= monounsaturated fatty acid; PUFA= polyunsaturated fatty acid; RV= right ventricle; $\mathrm{TV}=$ Total ventricle; $\mathrm{PSEM}=$ pooled standard error of the mean; NS=not significant; ${ }^{*} \mathrm{P}<0.05 ;{ }^{*} \mathrm{P}<0.01$.

the birds were in a normal range as noted by Julian (1987). Studies conducted by other investigators show that increasing dietary ALA seems to be a potential way to reduce $\mathrm{RVH}$ leading to ascites (Walton et al., 1999), mortality and the incidence of ascites at a high altitude (Bond et al., 1996) and the incidence of pulmonary hypertension syndrome (Walton et al., 2001). Potential of diets rich in ALA to prevent sudden death needs to be fully evaluated in a large-scale commercial setting and in environment more conducive to causing sudden death syndrome.

\section{Conclusion}

Increasing levels of dietary ALA enhanced the level of n-3 LCPUFA in heart tissues by 4 to 5 -fold but did not cause change in the percentage of RV to TV of birds. It appears clear that based on our data and the work of others, increasing ALA content in the diet of chickens could potentially be beneficial for the health of the birds; however, further work is necessary.

\section{Acknowledgement}

Portions of this research were done while the author was a postgraduate student at University of Adelaide, South Australia.

\section{References}

Albert, C. M., C. H. Hennekens, and C. J. O'Donnell. 1998. Fish consumption and risk of sudden cardiac death. Jama 279: 23-28.

Bond, J. M., R. J. Julian, and E. J. Squires. 1996. Effect of dietary flax oil and hypobaric hypoxia on right ventricular hypertrophy and ascites in broiler chickens. Br. Poult. Sci. 37: 731-741. 
Gardiner, E., J. Hunt, R. Newberry, and J. Hall. 1988. Relationship between age, body weight, and season of the year and the incidence of sudden death syndrome in male broiler chickens. Poult. Sci. 67: 1243-1249.

Julian, R. J. 1987. The effect of increased sodium in the drinking water on right ventricular hypertrophy, right ventricular failure and ascites in broiler chickens. Avian Pathol.16: 61-71.

Julian, R. J. 1998. Rapid growth problems: ascites and skeletal deformities in broilers. Poult. Sci. 77: 1773-1780.

Kartikasari, L. R., R. J. Hughes, M. S. Geier, M. Makrides and R. A. Gibson. 2012. Dietary alpha-linolenic acid enhances omega-3 long chain polyunsaturated fatty acid levels in chicken tissues. Prostaglandins Leukot. Essent. Fatty Acids. 87: 103-109.

Metcalf, R. G., M. J. James, R. A. Gibson. 2007. Effects of fish-oil supplementation on myocardial fatty acids in humans. Am. J. Clin. Nutr. 85: 1222-1228.
Olkowski, A. A. and H. L. Classen. 1998 High incidence of cardiac arrhythmias in broiler chickens. J. Vet. Med. A. 45: 83-91.

Olkowski, A. A. 2007. Pathophysiology of Heart Failure in Broiler Chickens: Structural, Biochemical, and Molecular Characteristics. Poult. Sci. 86: 9991005.

Wideman, R. F. 2001. Pathophysiology of heart/lung disorders: Pulmonary hypertension syndrome in broilers. World's Poult. Sci. J. 57: 289307

Walton, J. P., J. M. Bond, R. J. Julian and E. J. Squires. 1999. Effect of dietary flax oil and hypobaric hypoxia on pulmonary hypertension and haematological variables in broiler chickens. Br. Poult. Sci. 40: 385-391.

Walton, J. P., R. J. Julian and E. J. Squires. 2001. The effects of dietary flax oil and antioxidants on ascites and pulmonary hypertension in broilers using a low temperature model. Br. Poult. Sci. 42: 123-129. 